\title{
IMPASSE NO MODELO DE DESENVOLVIMENTO FLUMINENSE: O DESAFIO DE SUPERAR UMA CRISE ECONÔMICA E NÃO APENAS DAS FINANÇAS PÚBLICAS
}

\author{
IMPASSE ON RIO DE JANEIRO STATE DEVELOPMENT MODEL: THE CHALLENGE OF OVERCOMING AN ECONOMIC \\ CRISIS, NOT JUST PUBLIC FINANCE
}

\section{RESUMO}

O Estado do Rio de Janeiro enfrenta um grave problema econômico que não se resume a aparência dos fatos que compõe a narrativa oficial do governo. Aspectos prioritários na raiz da questão serão tratados no presente artigo, o que envolve impasses no modelo de desenvolvimento como também tensões federativas. Dessa forma, visa desmistificar certas falácias no debate. Primeiro, deixar claro que a crise não é um problema exclusivo estadual quando a escala do problema é nacional, logo, discutir suas especificidades. Segundo questionar se é razoável aceitar que governo federal assumindo papel só de credor, sem aceitar discutir assimetrias de poder no âmbito do pacto federativo. Terceiro, enfatizar a necessidade de articular uma solução para o problema das finanças públicas com os desafios de recuperação de uma grave crise econômica.

Palavras-chave: Rio de Janeiro. finanças públicas. desindustrialização.

\section{ABSTRACT}

The State of Rio de Janeiro faces a serious economic problem that does not resume the display of facts that make up the government's official narrative. Priority aspects at the root of the issue cannot be included in this paper, which involves deadlocks in the development model as well as federations. Thus, as it demystifies certain fallacies in the debate. First, make it clear that a crisis is not a state-only problem when a scale of the problem is national, logo, discusses its specifics. Second, the questionnaire is acceptable for the federal government to assume the role of the creditor without accepting to discuss power asymmetries within the federative pact. Third, emphasize the need for a joint solution to the public finance problem with the challenges of recovering from a serious economic crisis.

\section{Bruno Leonardo Barth Sobral ${ }^{\mathrm{a}, \mathrm{b}}$}

${ }^{\text {a }}$ Universidade do Estado do Rio de Janeiro (UERJ), Rio de Janeiro, RJ, Brasil

${ }^{\text {b }}$ Rede de Estudos em Planejamento e Política Pública Regional orientada ao Rio de Janeiro (Rede Pró-Rio), Rio de Janeiro, RJ, Brasil

DOI: $10.12957 /$ geouerj.2020.47272

Correpondência: brunoleo.rj@hotmail.com

Recebido em: 15 set. 2019 Revisado em: 23 out. 2019 Aceito em: $13 \mathrm{dez} .2019$

Keywords: Rio de Janeiro. public finances.deindustrialization 


\section{INTRODUÇÃO}

No segundo semestre de 2017, o governo do Estado do Rio de Janeiro formaliza o alinhamento com os interesses do governo federal através de um acordo específico para renegociação de suas dívidas. Oficialmente, é chamado de "programa de recuperação fiscal" por defensores e, informalmente, é chamado de "pacote de maldades" por opositores.

Para aqueles que acompanham de forma mais superficial a questão, tende a se julgar que se trata de um "socorro" financeiro. Inclusive, entre representantes políticos de outros estados, muitas vezes se teve o entendimento que se trata de um pleito a conferir privilégios ao Estado do Rio de Janeiro. Essa visão é reforçada pela própria atitude do governador fluminense que repete sem cessar que essa é a única alternativa e que isso seria, inclusive, do interesse dos servidores estaduais com enormes atrasos salariais.

Todavia, a questão é bem mais complexa que o discurso oficial sustenta, tornando necessária uma avaliação crítica. O governo estadual jaz prostrado na apuração de responsabilidades e figura como vítima fácil de intimidação que se traduz em bloqueio das contas e confisco. As obrigações com cláusulas inflexíveis e chicanas processuais não escondem a incompatibilidade com a capacidade de pagamento. Transparece na atual proposta federal um caráter punitivo para servir de exemplo e laboratório, sendo desconsiderada a urgência de medidas emergenciais e o reconhecimento das especificidades da estrutura e trajetória da economia regional fluminense.

O presente artigo pretende discutir um diagnóstico alternativo e perspectivas mais razoáveis para o enfrentamento do problema. Além dessa introdução e da conclusão, o artigo tem duas seções. Na segunda seção, aponta-se qual seria a raiz da questão e seus principais determinantes. Na terceira seção, questiona-se a retórica das contrapartidas impostas na proposta federal e se aponta outras opções políticas. Dessa forma, espera-se deixar claro que não se resume a um problema de gestão estadual. Ao invés disso, cabe enfatizar as responsabilidades federais sobre a crise no Estado do Rio de Janeiro e os desafios associados a dificuldade de superação de um estilo problemático de desenvolvimento estadual nas últimas décadas.

\section{A RAÍZ DA CRISE E SEUS PRINCIPAIS DETERMINANTES}

Quando se faz um diagnóstico é fundamental se separar a raiz do problema (vulnerabilidades latentes) dos fatores desencadeadores (agravamentos conjunturais). Os defensores do atual acordo com o governo federal colocam que a crise econômica nacional foi apenas um fator secundário que acelerou a evidência de um problema de gestão estadual: uma "gastança" com folha de pagamento que leva a um cumulativo descompasso entre receitas e despesas. Desse modo, seu ponto principal é a crítica ao que chamam de "rigidez orçamentária" em uma série de despesas obrigatórias que reduz os graus de liberdade para o ajuste fiscal. 
No geral, opositores ao acordo tendem a apontar que o problema não está centralmente no lado da despesa, e sim no lado das receitas. Uma interpretação corrente advoga que o problema de receita é principalmente por isenções fiscais. Assim, curiosamente, adota-se uma dimensão estratégica semelhante à visão dos defensores do pacote: a raiz está na gestão estadual. A diferença é que seria por renúncia à receita e não por uma suposta "gastança irresponsável". Dessa forma, também semelhante com a visão dos defensores do pacote, a crise econômica nacional é mencionada como um aspecto conjuntural apenas, logo, um fator secundário pouco enfatizado.

Ao invés de meros casos de gastança ou renúncia, defende-se que a raiz do problema é mais complexa e está nas características da debilidade produtiva estadual ${ }^{1}$, o que impede que as receitas públicas tenham outro comportamento (inclusive, reduzir dependência das rendas do petróleo e gás). É preciso ter clareza que não houve bonança econômica estadual desde a segunda metade dos anos 2000 a ser questionado se foi desperdiçada pelo ente público. O cerne da crítica deveria ser a negligência sobre indícios da desindustrialização nacional que atingem mais que proporcionalmente o Rio e que levaram a uma trajetória problemática de arrecadação, antes ocultada pelas rendas do petróleo e gás que despencaram recentemente.

Conforme figura 1, entre 2014 e 2016, a retração da economia petrolífera significou uma perda de R\$ 4,8 bilhões em receita pública. Só em 2015, caiu para quase a metade o peso das rendas com royalties e participações especiais na receita total, regredindo a um patamar sem precedentes. Porém, o cenário negativo não se deveu apenas a indústria extrativa. Quando se analisa a evolução da arrecadação de ICMS (figura 2), nota-se também a trajetória de forte retração nos últimos anos, o que reflete a pouca contribuição da indústria de transformação (só um pouco mais de 1/4 do total arrecadado nesse imposto). Diante disso, explicitou-se um desempenho tributário estruturalmente aquém do porte de sua economia regional.

Portanto, cabe se avaliar melhor os impactos nas finanças públicas de uma "estrutura produtiva oca" (SOBRAL, 2013 e 2017). Entende-se esse último fenômeno como um processo de desadensamento de importantes cadeias de produção levando ao agravamento das condições que impedem a indústria de transformação se constituir no motor chave do crescimento econômico e do progresso técnico. Nesse sentido, trata-se de um esvaziamento que leva ao esgarçamento do tecido produtivo e a ociosidade de uma série de recursos no território. Isso ocorre por uma perda de diversificação e complexidade produtiva a partir de uma trajetória centrada na capacidade de sobrevivência operacional com menor valor agregado (conteúdo local).

${ }^{1}$ Controvérsias tributárias e tensões federativas agravam esse quadro, como será discutido na próxima seção. 
Figura 1. Peso (\%) de Royalties e Participações Especiais na Receita Total do governo fluminense, 2003/2015 Fonte: Contas de Gestão 2015 / SEFAZ-RJ

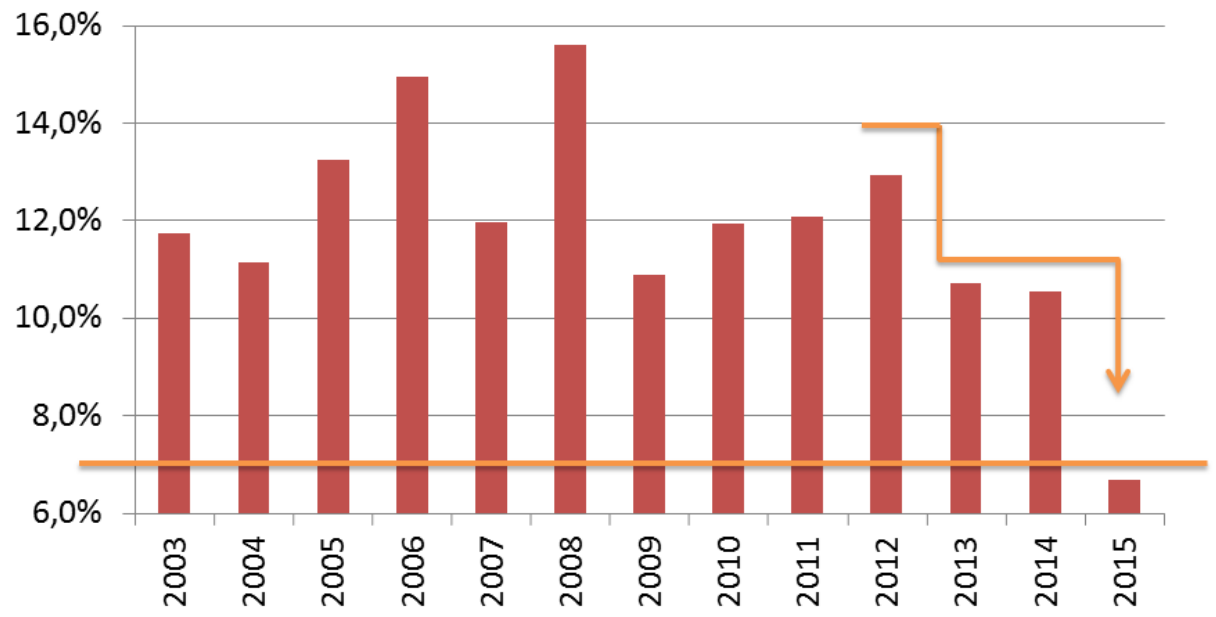

Figura 2. Variação real da arrecadação fluminense de ICMS (12 meses acumulados) decomposta por setores, 1998/2016 Fonte: Dweck (2017) a partir de dados BCB

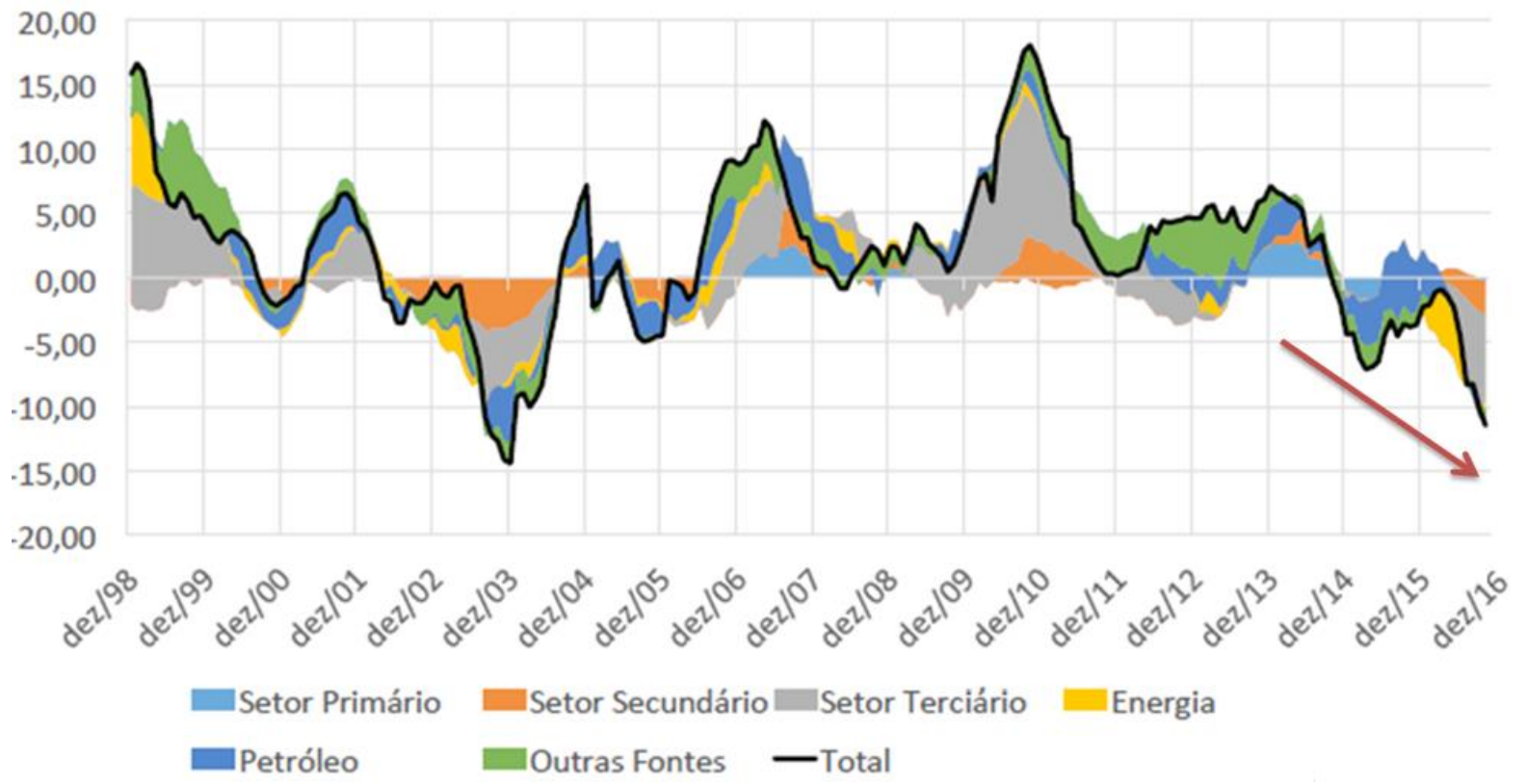

Portanto, a noção de "estrutura oca" se associa a um conjunto disperso de especializações setoriais em uma região e com pouca coerência do ponto de vista de uma divisão territorial do trabalho. Como consequência, revela uma economia muito dependente do aproveitamento de algumas vantagens já reveladas que passam a ser consideradas suas "vocações" por suas elites decisórias, inclusive, muitas vezes provocando situações de euforia exagerada sobre suas potencialidades. Embora existam brechas para alguns ganhos de competitividade em nichos setoriais isolados, não há o enfrentamento dos problemas estruturais, o que impede o surgimento de novas vantagens competitivas mais sistêmicas. Isso significa que ainda que seja possível listar um conjunto de atividades dinâmicas, estes não são setores líderes a ponto de gerar efeitos indutores e poder de arrasto significativos 
Por essa razão, a base produtiva como um todo fica fragilizada ainda que possam ocorrer ciclos expansivos, inclusive decisões de grandes investimentos. Isso significa que se mantém os riscos de regressão generalizada a depender do grau que estiver vulnerável aos efeitos negativos de conjunturas adversas. Dito em outras palavras, é uma economia mais suscetível a sofrer (e com mais intensidade) os rebatimentos de qualquer crise internacional e nacional.

Atualmente, o governo tem uma arrecadação incompatível com suas despesas não porque gasta muito ou renuncia muito a tributos, e sim por essa "estrutura produtiva oca" vulnerável a graves crises nacionais. Especializada em só alguns nichos setoriais com pouco adensamento produtivo, é grave a tendência de perda de valor agregado e que foi acelerada recentemente.

Como ilustração, a figura 3 apresenta a evolução do crescimento do valor adicionado bruto total do Estado do Rio de Janeiro e da média nacional, período 2002/2014. Nota-se que, no acumulado, o estado do Rio de Janeiro possui desempenho pior e somente em dois anos se aproximou da média nacional: 2009 e 2014. Justamente anos cuja trajetória do VAB total para o Brasil sofreu piora, ou seja, a aproximação foi porque o Brasil foi mal e não porque o Estado do Rio de Janeiro foi bem. Quando a economia brasileira vai bem, a economia fluminense não acompanha na mesma intensidade.

Figura 3. Série encadeada do crescimento do volume do valor adicionado bruto (VAB) total, 2002-2014 Fonte: Contas Regionais / IBGE

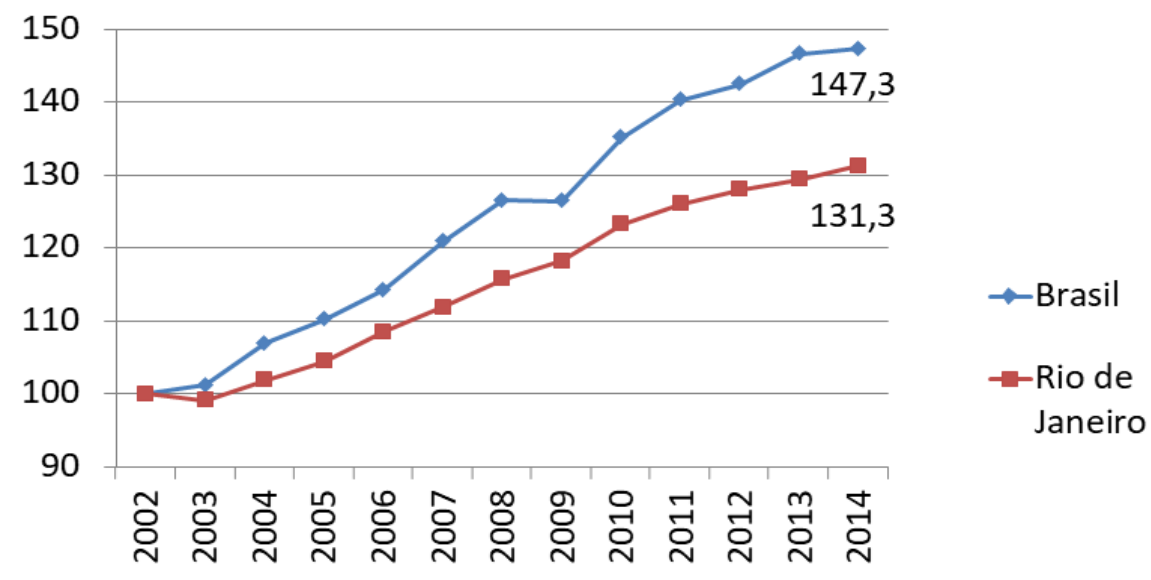

Além disso, cabe destacar a evolução problemática da relação Valor da Transformação Industrial e Valor Bruto da Produção Industrial (VTI/VBPI). Conforme figura 4, nota-se uma trajetória decrescente no período 1996-2014 tanto para o Estado do Rio de Janeiro como para o Brasil. Apesar dessa relação apresentar valores superiores para o caso fluminense em todos os anos analisados, é preocupante como comparativamente essa trajetória é mais irregular e como, ocorreu uma queda bem mais acentuada nos últimos anos que foram mais 
afetados por um cenário de crise. Isso sugere como essa base industrial está estruturalmente mais vulnerável às conjunturas adversas.

Figura 4. Evolução da relação Valor da Transformação Industrial / Valor Bruto da Produção Industrial para a indústria de transformação fluminense e no Brasil, 1996-2014. Fonte: PIA/IBGE

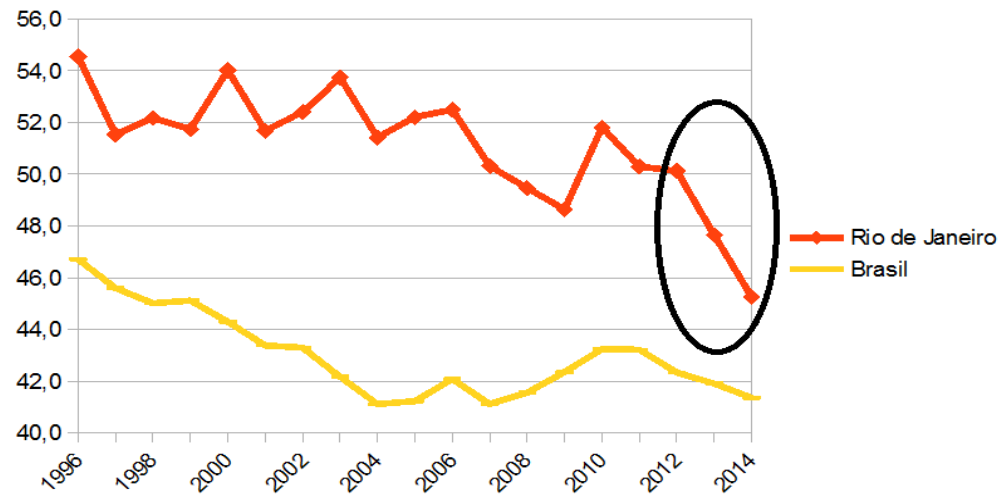

Atualmente, apenas três setores representam em torno da metade da estrutura da indústria de transformação, quando os mesmos representavam apenas 22,9\% em 1970 como mostram as tabelas 1 e 2 . Trata-se dos seguintes setores: "Metalurgia" (inclui produção siderúrgica); "Derivados do petróleo" (destacando-se atividade de refino); e "Produtos químicos" (inclui atividade petroquímica). Cabe ponderar que a clareza sobre esse diagnóstico pode ser afetada por momentos mais intensos de um cenário de crise nacional (e internacional) e períodos nos quais irrompem crises setoriais e saturação dos mercados específicos. Isso explica 2009 e 2014 serem os anos mais recentes que a participação da soma desses setores destacados terem levemente se reduzido. Trata-se de ocasiões que se debilitaram justamente alguns dos nichos setoriais que se tinham uma competitividade destacada (por exemplo, setores ligados à economia do petróleo e a produção de aço). Portanto, isso não deve ser entendido como uma reversão do quadro estrutural negativo no qual se reduziu sensivelmente a diversificação verificada em 1970.

Nesse ponto que o questionamento dos incentivos fiscais ganha pertinência por não terem revertido esse quadro de especialização prematura, logo, o questionamento à eficácia de uma política ao exigir maior detalhamento dos resultados para seu aperfeiçoamento e não como um volume financeiro a sanar um desajuste fiscal. Como lembra Mauro Osorio (2016), isso é agravado pelo Estado do Rio de Janeiro ser triplamente prejudicado por decisões tomadas na escala federal sobre a tributação do setor petrolífero: 1) a legislação brasileira impede o estado de cobrar ICMS sobre a extração do petróleo; 2) através do Repetro, impacto no fluxo de caixa do governo ao adiar o recebimento do valor do ICMS que seria cobrado sobre a compra dos equipamentos e matérias primas utilizados para viabilizar essa extração (realiza um diferimento); 3) pela Lei Kandir, desoneração federal sobre ICMS quando o petróleo extraído no Rio é exportado, provocando a controvérsia sobre o cálculo e o pagamento das restituições devidas. 
Tabela 1. Participação de segmentos destacados (\%) no VTI da indústria de transformação do Estado do Rio de Janeiro, $1970-2002$. Fonte: Censos Industriais (1970-1985) e PIA - IBGE (1996-2002)

\begin{tabular}{l|c|c|c|c|c}
\hline & 1970 & 1980 & 1985 & 1996 & 2002 \\
\hline Metalúrgica Básica & 8,6 & 9,7 & 11,9 & 12,9 & 14,6 \\
\hline Derivados de Petróleo e Álcool & 8,1 & 4,9 & 10,2 & 9,7 & 19,3 \\
\hline Outros Produtos Químicos & 6,2 & 9,0 & 11,7 & 8 & 7,7 \\
\hline Soma dos segmentos destacados & $\mathbf{2 2 , 9}$ & $\mathbf{2 3 , 6}$ & $\mathbf{3 3 , 8}$ & $\mathbf{3 0 , 6}$ & $\mathbf{4 1 , 6}$ \\
\hline Total da indústria de transformação & 100,00 & 100,00 & 100,00 & 100,00 & 100,00 \\
\hline
\end{tabular}

Tabela 2. Participação de segmentos destacados (\%) no VTI da indústria de transformação do Estado do Rio de Janeiro, 2007-2014 Fonte: PIA - IBGE

\begin{tabular}{l|c|c|c|c}
\hline & 2007 & 2009 & 2011 & 2014 \\
\hline $\begin{array}{l}\text { Fabricação de coque, de produtos derivados do petróleo e de } \\
\text { biocombustíveis }\end{array}$ & 30,8 & 28,9 & 34,6 & 24,5 \\
\hline Fabricação de outros produtos químicos & 7,4 & 8,4 & 7,2 & 10,2 \\
\hline Metalurgia & 14,4 & 9,5 & 9,7 & 9,7 \\
\hline Soma dos segmentos destacados & $\mathbf{5 2 , 5}$ & $\mathbf{4 6 , 8}$ & $\mathbf{5 1 , 4}$ & $\mathbf{4 4 , 4}$ \\
\hline Indústrias de transformação & 100,0 & 100,0 & 100,0 & 100,0 \\
\hline
\end{tabular}

Nesse sentido, a crise econômica nacional está longe de ser só um fator secundário. E se ela é algo central, então a crise no Estado do Rio de Janeiro tem que ser urgentemente nacionalizada para enfrentar suas especificidades fundamentais. Antes que um problema que se resume a desajustes em finanças públicas, se trata de uma economia estadual em uma situação grave com reflexos sociais preocupantes. Conforme figura 5, se em 2015, a variação absoluta da média anual de ocupados ainda aumentou em 6 mil, em 2016, foram extintos 176 mil postos de trabalho. No 2ㅇsemestre de 2016, a taxa de desocupação já era superior à média nacional após mais que dobrar em apenas dois anos, como mostra a figura 6 .

Figura 5. Variação absoluta da média anual de ocupados sobre ano anterior na economia fluminense, 2012/2016 Fonte: PNADC/IBGE

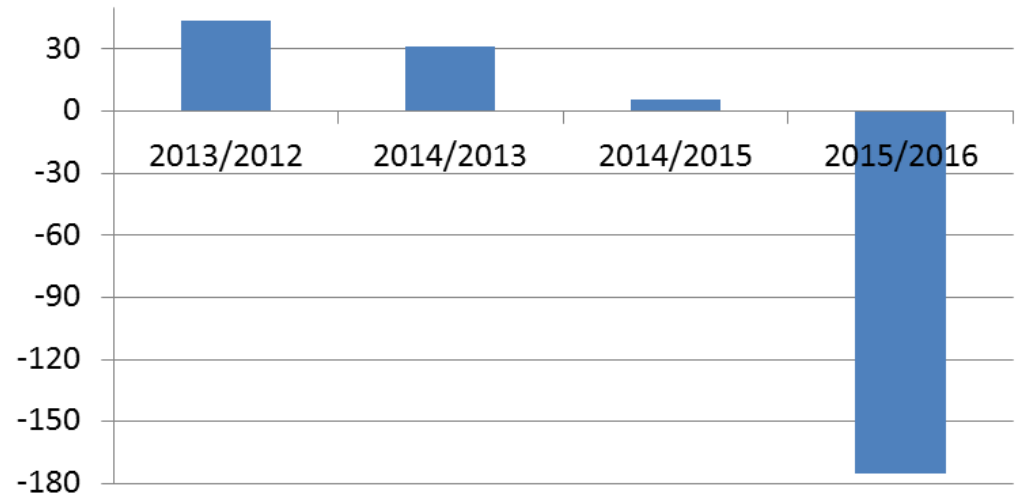

Figura 6. Evolução da taxa de desocupação (\%) do Estado do Rio de Janeiro e do Brasil Fonte: PNADC/IBGE 


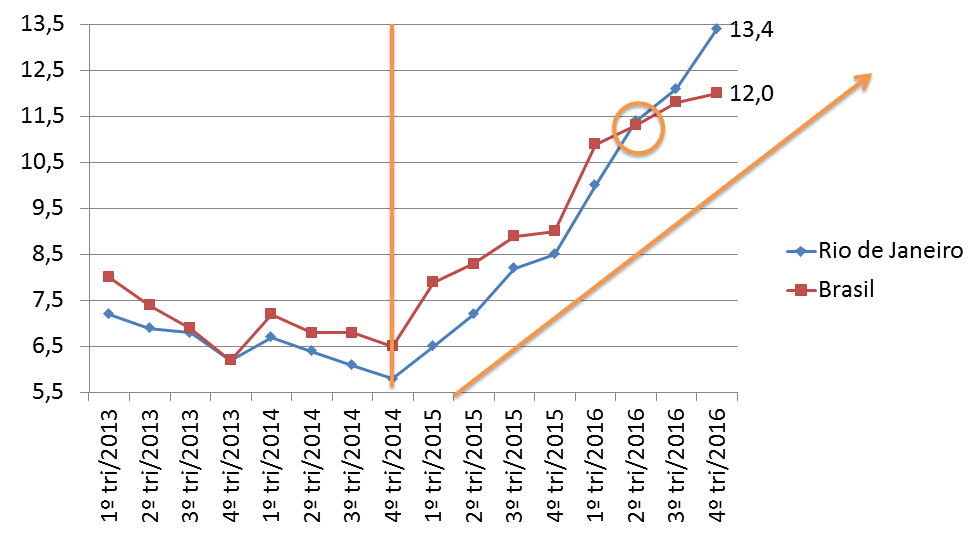

\section{O EQUÍVOCO DA RETÓRICA IMPOSTA PELO GOVERNO FEDERAL E OUTRAS OPÇÕES POLÍTICAS ALTERNATIVAS}

A crise no Rio de Janeiro se explicita em um contexto onde a gestão pública sofre três problemas simultaneamente: uma grande dificuldade de caixa associada a uma trajetória descontrolada de déficits primários sob o efeito da crise nacional, um processo de endividamento explosivo já sob um comportamento especulativo e uma máquina pública não inchada, logo, sem possibilidade de políticas de austeridade oferecem resposta significativa. Uma análise crítica deve associar o diagnóstico desses três pontos para questionar como o acordo federal proposto não busca uma solução e sim postergar com tendência a agravamento do quadro em uma temporalidade alongada.

É preciso ter claro que a dimensão mais aparente do problema é inúmeras dificuldades correntes de caixa para cumprir o orçamento público. Isso exige algumas ponderações. Por exemplo, segundo figura 7, entre 2012 e 2016, acumula-se mais de $\mathrm{R} \$ 30$ bi de déficits primários em termos reais (desconsiderando ganho com valor dos depósitos judiciais em 2015). Porém, o saldo acumulado é positivo (mais de $\mathrm{R} \$ \$$ bi) em termos reais considerando junto às últimas três gestões (2003 e 2016).

Figura 7. Resultado primário do governo fluminense em termos reais, 2003/2016 Fonte: SEFAZ/RJ Nota: Valores corrigidos pelo IPCA (dez/2016)

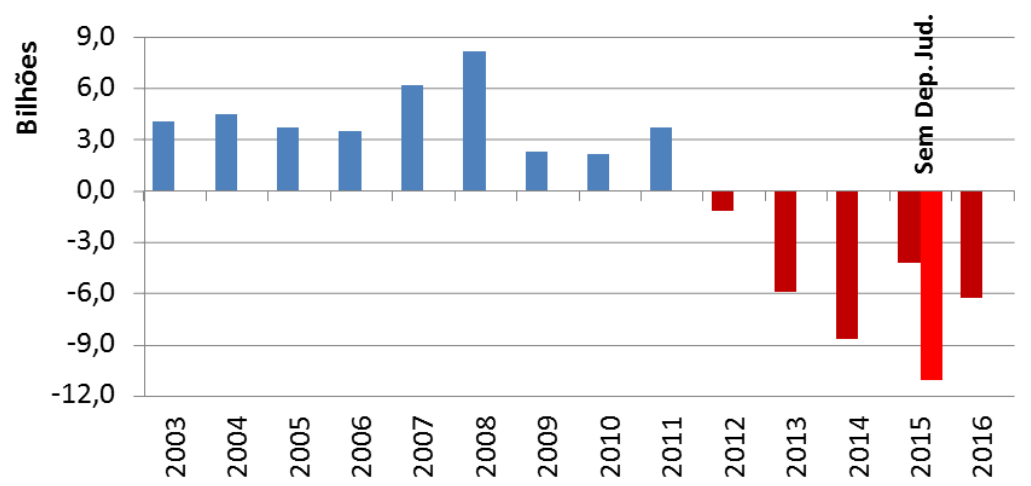


De certo, equivoca-se quem mantém a conviç̧ão que se trata de um problema de "gastança" pública. Afinal, o desajuste fiscal reflete uma maior queda real das receitas primárias que das despesas primárias, o que guarda especificidades. Segundo figura 8, em 2016, a receita primária já era quase 1/3 menor que aquela em 2014 (mais de R\$ 20 bi a menos), a ponto de chegar ao menor patamar perante as últimas três gestões. É preciso ter claro que se estabeleceu um ciclo vicioso no qual se faz progressivamente maiores cortes de despesas (e ainda se continua recomendando que se faz mais) e as receitas caem ainda mais. Não se priorizando uma inflexão na deterioração das receitas, o desajuste fiscal persiste tornando inócua a aposta reiterada em maiores endividamentos e redução da máquina pública, em particular, no contexto atual de recessão e carências sociais.

Como mostra a figura 9, já há uma exposição temerária a um endividamento acelerado, o que foi induzido pelo governo federal em três fases. No início, isso se justificava para fazer investimentos de interesse nacional que não foram realizados diretamente pelo governo federal, apoiando o endividamento dos governos estaduais para fazerem no seu lugar.

Figura 8. Evolução de receitas e despesas primárias do governo fluminense em termos reais, 2001/2016 Fonte: SEFAZ-RJ Nota: Valores corrigidos pelo IPCA (dez/2016)

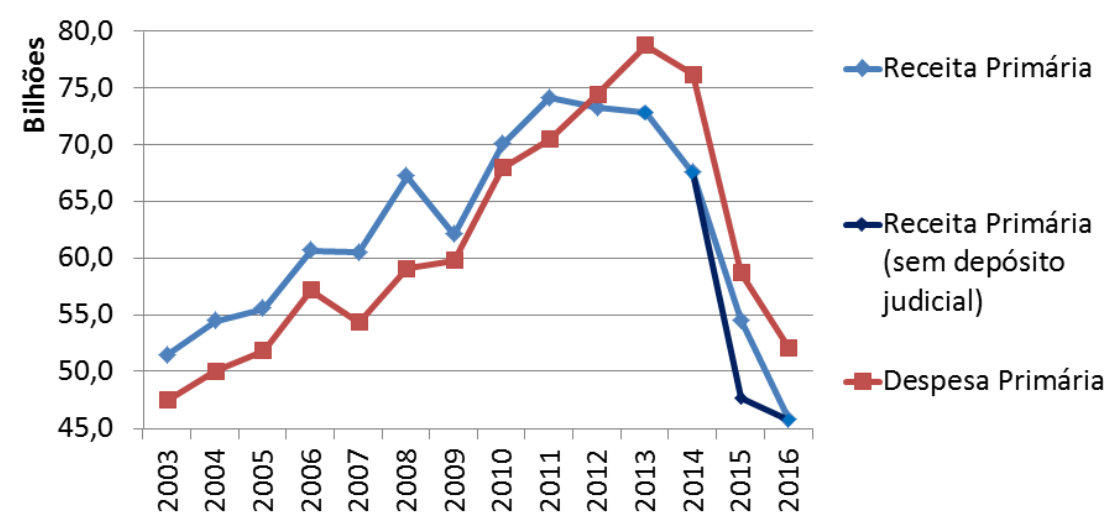

Figura 9. Evolução da Dívida Consolidada Líquida em \% da Receita Corrente Líquida de estados selecionados, 2006/2016 Fonte: Tesouro Nacional e Secretarias de Fazenda estaduais Nota: posição em 31/01/2017

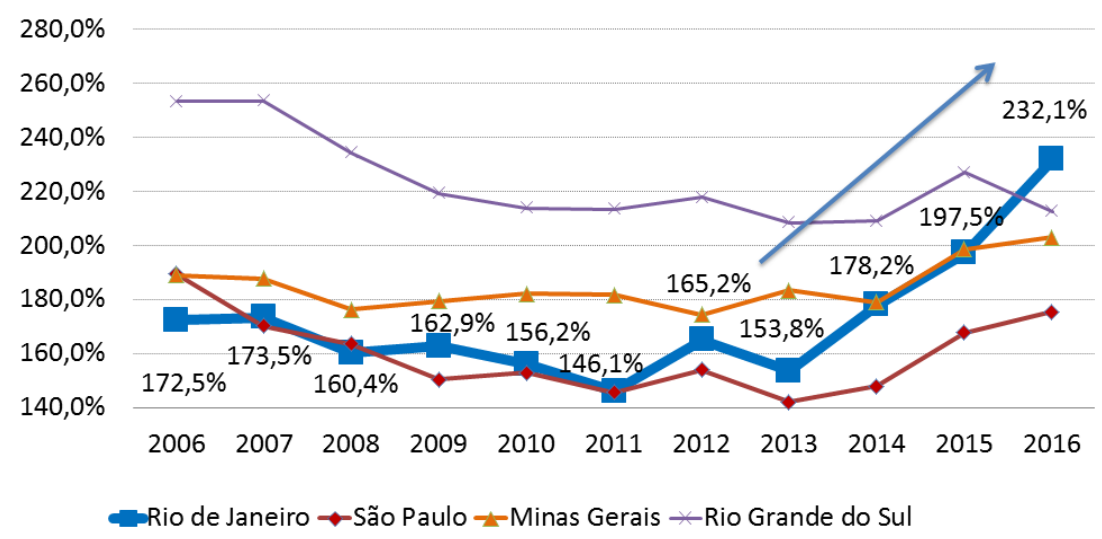


Numa segunda fase, houve a tentativa de sustar temporariamente os efeitos de uma recessão nacional que se julgava passageira no discurso oficial federal. Porém, ao se alongar, transformou esse processo em uma “bola de neve". Segundo figura 10, entre 2012 a 2015, foram contratados R\$22,39 bilhões em empréstimos. Nesse ponto, cabe ainda destacar as obrigações no valor de R\$ 18,4 bilhões até 2021 pela antecipação de R\$ 8,4 bilhões em royalties e participações especiais no período recente. Consequentemente, já há um alto patamar de desembolsos obrigatórios para os próximos 10 anos (no total, em torno de R\$ 82 bilhões), como aponta a figura 11.

Figura 10. Operações de crédito realizadas do governo fluminense, 2008/2016 Fonte: SEFAZ-RJ

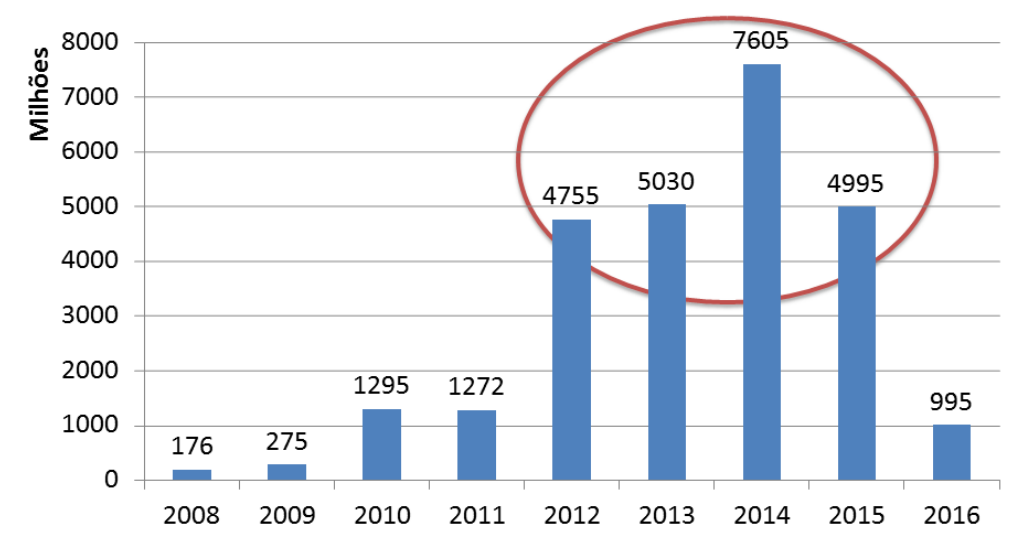

Figura 11. Cronograma de desembolsos com amortizações e encargos da dívida pública do governo fluminense, 2017/2049 Fonte: SEFAZ-RJ

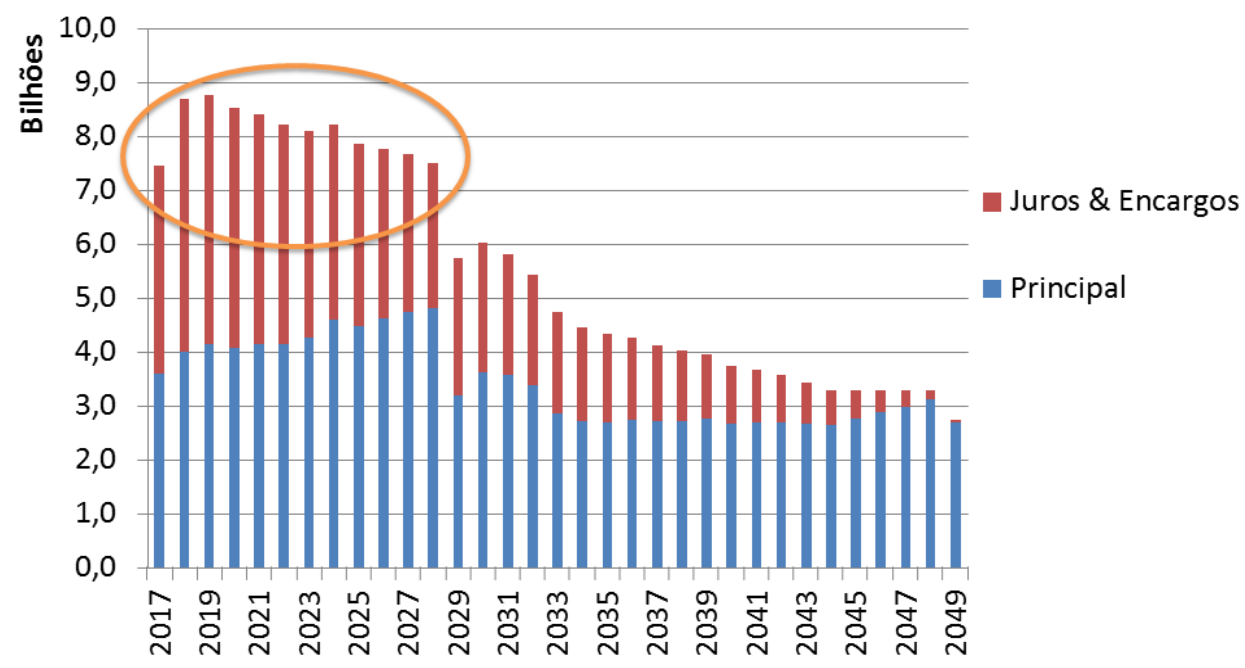

No momento atual, transcorre a terceira fase quando a gestão federal tenta fazer seu ajuste das contas diretamente à custa dos entes subnacionais como o Estado do Rio de Janeiro. Ao impedir que financie seu déficit através do orçamento como o mesmo fez, empurra a gestão fiscal estadual para um comportamento cada vez mais especulativo: endividamento crescente, numa lógica de dívida sobre dívida. 
Cabe desmistificar a falsa impressão que o acordo proposto garante a recuperação da economia fluminense. Tão somente retira autonomia fiscal do governo estadual em troca de uma "fuga para frente" de um quadro insustentável. Não se articula a qualquer plano de desenvolvimento nacional nem reserva nenhuma parte do orçamento federal para enfrentar a questão. Apenas se está flexibilizando algumas condições como credor financeiro, autorizando o governo estadual a antecipar receitas em troca de vender patrimônio e se endividar em uma situação fiscal mais arriscada. Sem alterar a estrutura de endividamento, revela-se uma chantagem institucional, porque, caso contrário, a justiça autorizará mais arrestos e bloqueios sem questionar os graves efeitos socioeconômicos.

O que os defensores do pacote federal chamam de "medidas estruturais" são severas contrapartidas que desconsideram o efeito multiplicador do gasto público e o papel das políticas públicas. Sobre essa nomenclatura vistosa, "medidas estruturais", esconde aquilo que é exigido de forma inegociável para demonstrar que está retomando capacidade de pagamento da dívida com governo federal e, assim, não ter o acordo sustado (com novos bloqueios e arrestos). Logo, não se trata da defesa dos interesses do Rio, e sim de atender os termos impostos pelo credor federal.

Insistir em mais endividamento tendo a retórica do "dever de casa" sobre contrapartidas como algo indiscutível é desconsiderar que, daqui para frente, economias substanciais só serão feitas sucateando ou cortando serviços públicos com o descuido na preservação de fatores portadores de futuro (vide a agonia da UERJ entre tantos outros exemplos). Como aponta a figura 12, a evolução das Despesas Primárias em percentual da Receita Corrente Líquida - RCL revela um violento tranco nos dispêndios. 2016 foi o ano com menor patamar atingido por esse indicador considerando desde o início da década de 2000, mesmo com a RCL sofrendo uma queda considerável nos últimos anos.

Figura 12. Evolução das Despesas Primárias em percentual da Receita Corrente Líquida, 2001/2016 Fonte: Contas de Gestão / SEFAZ/RJ Nota: Dados de 2015 não consideram depósitos judiciais

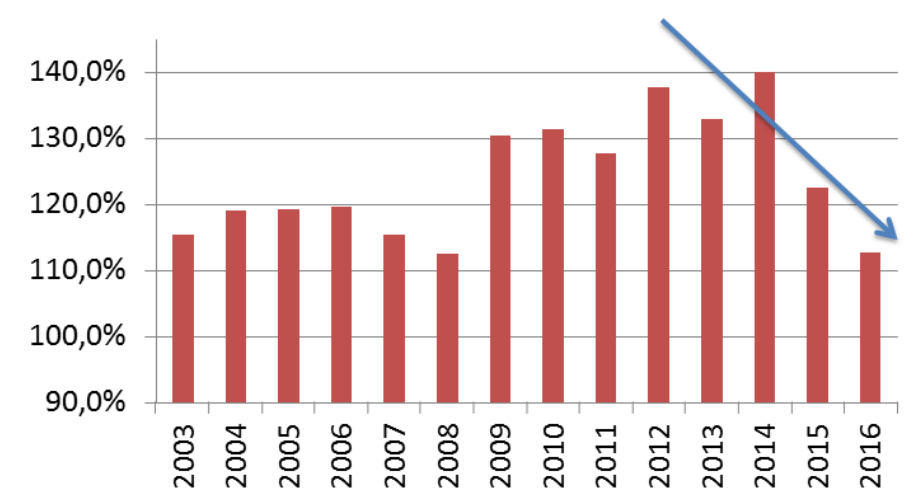

Todo o debate que foca exclusivamente nas finanças públicas acaba enfatizando a folha de pagamentos sem contextualizar como o efeito de um problema maior e com outras especificidades. É fundamental que 
todo o debate de finanças públicas não desconsidere a dimensão da economia regional e seus desafios que tornam necessário a recuperação e sustentação de instituições de Estado com visão de futuro. No caso fluminense, falta-se ainda fortalecer diversas áreas, recompondo defasagens salariais e mais concursos públicos.

Uma análise da evolução da remuneração média no setor público estadual do Rio de Janeiro diante da mesma evolução para todos os setores e comparando com as respectivas médias nacionais permite destacar aspectos pouco considerados no debate até o momento. Segundo a tabela 3, entre 2006 e 2010, houve uma queda do Rio de Janeiro no ranqueamento de remunerações do setor público dos estados (8ำ para 12ํํ), inclusive, em 2010, estava abaixo da média nacional. Entre 2010 e 2015, houve uma recuperação (12ำ para 9)), mas sem equiparar a posição de 2006 (8ํ).

Tabela 2. Comparativo $2003 \times 2012$ - Todas as viagens realizadas, por modo de transporte (em milhares) Fonte: Relatório 4, PDTU 2013-2015, p. 165 Fonte: Rais / MTE (valores nominais)

\begin{tabular}{lcccccc}
\hline & \multicolumn{2}{c}{2006} & \multicolumn{2}{c}{2010} & \multicolumn{2}{c}{2015} \\
& Rank & Valor & Rank & Valor & Rank & Valor \\
\hline Distrito Federal & 1 & $3.687,07$ & 1 & $5.706,84$ & 1 & $7.938,68$ \\
Santa Catarina & 6 & $2.089,02$ & 4 & $3.377,73$ & 2 & $6.432,28$ \\
Amapá & 2 & $2.769,89$ & 2 & $3.682,10$ & 3 & $6.230,89$ \\
Mato Grosso & 11 & $1.823,72$ & 3 & $3.629,69$ & 4 & $5.935,85$ \\
Minas Gerais & 10 & $1.888,84$ & 14 & $2.554,49$ & 5 & $5.686,86$ \\
Mato Grosso do Sul & 5 & $2.090,39$ & 6 & $3.127,54$ & 6 & $5.487,70$ \\
Paraná & 7 & $1.983,22$ & 7 & $3.047,11$ & 7 & $5.332,32$ \\
Bahia & 17 & $1.707,64$ & 10 & $2.706,84$ & 8 & $5.193,81$ \\
Rio de Janeiro & 8 & $1.937,75$ & 12 & $2.650,00$ & 9 & $5.187,49$ \\
Espírito Santo & 4 & $2.121,88$ & 5 & $3.343,15$ & 10 & $5.005,70$ \\
Pará & 21 & $1.542,15$ & 17 & $2.424,82$ & 11 & $4.784,52$ \\
Goiás & 14 & $1.767,12$ & 13 & $2.567,59$ & 12 & $4.671,54$ \\
Rio Grande do Sul & 12 & $1.810,70$ & 15 & $2.553,51$ & 14 & $4.469,73$ \\
São Paulo & 9 & $1.925,31$ & 11 & $2.684,48$ & 16 & $4.210,51$ \\
Média nacional & - & $1.861,08$ & - & $2.703,24$ & - & $4.697,02$ \\
\hline
\end{tabular}

Por outro lado, segundo a tabela 4, o comparativo de remuneração revela que a proporção em "Todos os setores - RJ" (vis à vis "Setor Público estadual - BR") foi sempre maior que em "Setor público estadual RJ" (vis à vis "Setor público estadual - BR). Isso indica que nunca houve um diferencial relativo, em termos de impacto nacional, para a remuneração do setor público local diante daquela para o total de suas atividades. Entre 2006 e 2010, houve afastamento da equivalência, e, entre 2010 e 2015, houve uma reaproximação, mas ainda sem equiparar a mesma proporção. Se fosse proporcional ao porte da economia regional, em 2015, a 
remuneração média no setor público estadual deveria ser $\mathrm{R} \$ 5.523,69$, ou seja, ainda $\mathrm{R} \$ 336,20$ a mais ${ }^{2}$. Portanto, a remuneração média no setor público estadual ainda possui uma defasagem relativa. Soma-se a isso a baixa expansão dos empregos formais no setor público estadual fluminense nas últimas gestões estaduais, como mostra a tabela 5. Inclusive, houve uma retração de 5,0\% no período 2010/2015.

Tabela 4. Comparativo da remuneração média no setor público estadual e em todos os setores entre Estado do Rio de Janeiro e média dos estados brasileiros, 2006/2015 Fonte: Rais / MTE (valores nominais). Nota: sob a sigla BR está a média dos estados brasileiros

\begin{tabular}{|c|c|c|c|c|c|c|}
\hline & \multicolumn{2}{|c|}{2006} & \multicolumn{2}{|c|}{2010} & \multicolumn{2}{|c|}{2015} \\
\hline & $\%$ & Valor & $\%$ & Valor & $\%$ & Valor \\
\hline Setor público estadual - BR & $100,0 \%$ & $1.861,08$ & $100,0 \%$ & $2.703,24$ & $100,0 \%$ & $4.697,02$ \\
\hline Setor público estadual - RJ & $104,1 \%$ & $1.937,75$ & $98,0 \%$ & $2.650,00$ & $110,4 \%$ & $5.187,49$ \\
\hline Todos os setores - BR & $100,0 \%$ & $1.169,58$ & $100,0 \%$ & $1.588,42$ & $100,0 \%$ & $2.450,59$ \\
\hline \multirow[t]{4}{*}{ Todos os setores - RJ } & $113,7 \%$ & $1.329,89$ & $115,7 \%$ & $1.837,35$ & $117,6 \%$ & $2.881,88$ \\
\hline & \multicolumn{6}{|c|}{2015} \\
\hline & $\%$ & \multicolumn{2}{|c|}{ Valor nominal } & $\%$ & \multicolumn{2}{|c|}{ Valor nominal } \\
\hline & \multicolumn{3}{|c|}{ Dados Reais } & \multicolumn{3}{|c|}{ Simulação de Proporcionalidade } \\
\hline Setor público estadual - BR & $100,0 \%$ & \multicolumn{2}{|c|}{$4.697,02$} & $100,0 \%$ & \multicolumn{2}{|c|}{$4.697,02$} \\
\hline Setor público estadual - RJ & $110,4 \%$ & \multicolumn{2}{|c|}{$5.187,49$ (a) } & $117,6 \%$ & \multicolumn{2}{|c|}{$5.523,67$ (b) } \\
\hline Todo os setores - BR & $100,0 \%$ & \multicolumn{2}{|c|}{$2.450,59$} & Defasagem: & \multirow{2}{*}{\multicolumn{2}{|c|}{$-336,18$}} \\
\hline Todos os setores - RJ & $117,6 \%$ & \multicolumn{2}{|c|}{$2.881,88$} & $(a-b)$ & & \\
\hline
\end{tabular}

Tabela 5. Expansão do número de empregos formais no setor público estadual em regiões selecionadas, 2006/2015 Fonte: Osorio (2016) a partir de RAIS/MTE

\begin{tabular}{llllll}
\hline & 2006 & 2010 & 2015 & $\begin{array}{l}\text { Var (\%) } \\
2006-2015\end{array}$ & $\begin{array}{l}\text { Var (\%) } \\
2010-2015\end{array}$ \\
\hline Região Sudeste & 1.297 .529 & 1.498 .627 & 1.276 .729 & $-1,6$ & $-14,8$ \\
Minas Gerais & 253.900 & 313.537 & 217.878 & $-14,2$ & $-30,5$ \\
Espírito Santo & 52.917 & 53.519 & 53.433 & 1,0 & $-0,2$ \\
Rio de Janeiro & 247.670 & 263.728 & 250.524 & 1,2 & $-5,0$ \\
São Paulo & 743.042 & 867.843 & 754.894 & 1,6 & $-13,0$ \\
Região Sul & 422.479 & 401.819 & 418.619 & $-0,9$ & 4,2 \\
Região Norte & 327.273 & 420.629 & 397.164 & 21,4 & $-5,6$ \\
Região Nordeste & 752.340 & 830.688 & 764.497 & 1,6 & $-8,0$ \\
Região Centro-Oeste & 352.357 & 357.072 & 346.174 & $-1,8$ & $-3,1$ \\
Brasil & 3.151 .978 & 3.508 .835 & 3.203 .183 & 1,6 & $-8,7$ \\
\hline
\end{tabular}

Esses aspectos deveriam ser considerados ao avaliar os reajustes salariais conseguidos em anos anteriores, desmistificando a falsa impressão de que necessariamente significam exageros. Segundo figura 13, em 2015, diferente de Minas Gerais e Rio Grande do Sul, o peso das despesas com pessoal no total de despesas primárias ainda foi um resultados mediano no comparativo com os outros estados brasileiros. Deve-se ponderar que há uma tentativa de maiores cortes em todas as despesas não obrigatórias, logo, as despesas

\footnotetext{
2 Essa análise não discute as discrepâncias salariais entre as várias categorias, o que pode ter sido agravado por algumas ter obtido diversos reajustes no período recente e outras continuarem sem reajuste algum.
} 
primárias tendem a se concentrar nas obrigatórias (como despesas com pessoal), o que aumentará provavelmente o valor desse indicador nos próximos exercícios.

É importante ter claro que, em particular, o poder executivo no Estado do Rio de Janeiro tem uma máquina pública ainda pouco estruturada. Isso é um problema histórico fruto de décadas de desorganização dessa máquina, como apontou Osorio (2005). Nesse aspecto, o Estado nem está perto de uma execução ótima para questionar seu tamanho, dado que ainda se gasta insatisfatoriamente em atividades fins. Portanto, ao se discutir um ajuste que se foque então em atividades meio, e que se dê maior espaço no orçamento para atividades fim, como os custeios de saúde e educação. Conforme tabela 6, em 2015, o gasto per capita de funções ligadas ao Legislativo, Judiciário, Ministério Público e Defensoria é em torno de 50\% maior no Rio de Janeiro do que em São Paulo e Minas Gerais. Inversamente, em saúde e educação o gasto per capita é menor comparativamente.

Figura 13. Peso (\%) das despesas com pessoal no total de despesas primárias por estados, 2015 Fonte: Programa de Reestruturação e Ajuste Fiscal / STN.

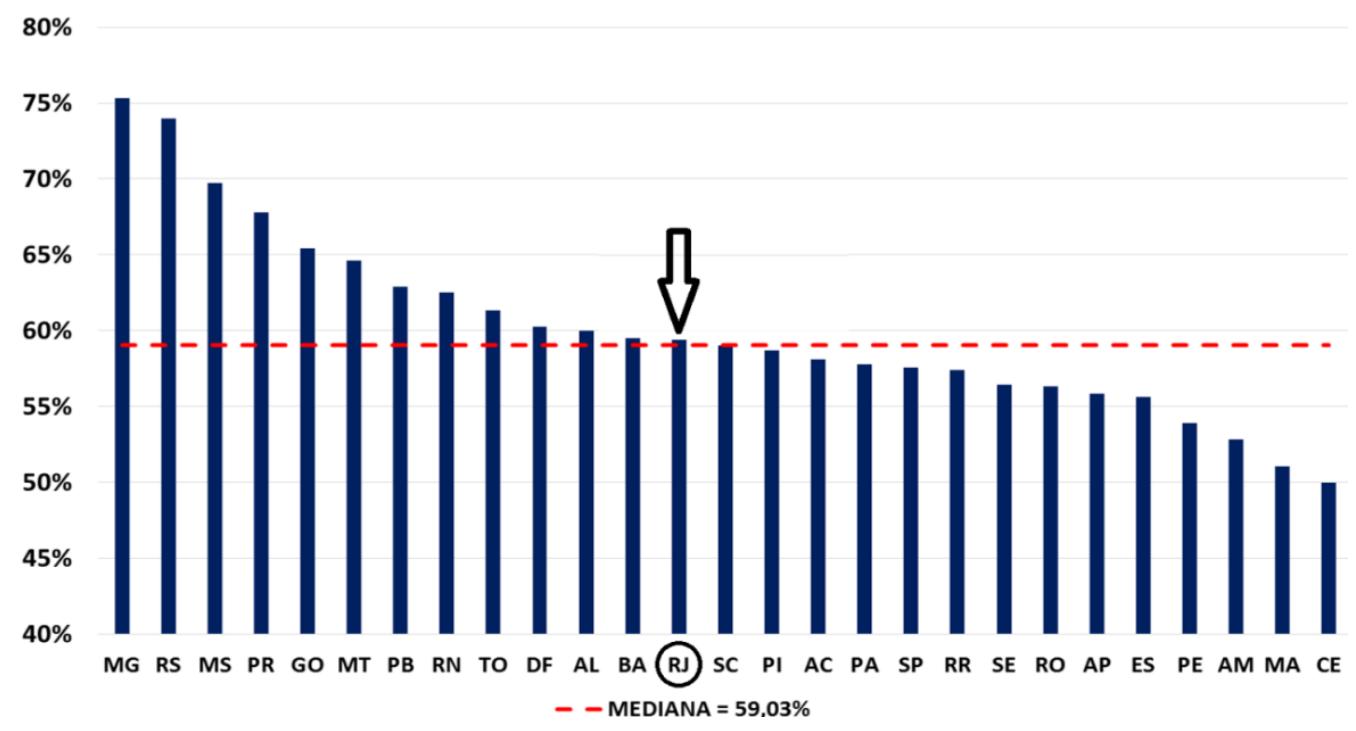

Tabela 6. Gasto per capita por funções nas administrações estaduais de Rio de Janeiro, São Paulo e Minas Gerais, 2015 Fonte: Osorio (2016) a partir de dados de SEFAZ do RJ, SP e MG

\begin{tabular}{cccc}
\hline Despesas por funções & Rio de Janeiro & São Paulo & $\begin{array}{c}\text { Minas } \\
\text { Gerais }\end{array}$ \\
\hline Legislativo & 76,88 & 29,40 & 55,64 \\
Judiciário & 239,44 & 188,39 & 169,30 \\
MP e Defensoria & 126,07 & 75,87 & 72,62 \\
Segurança & 525,10 & 253,68 & 624,16 \\
Educação & 374,34 & 724,15 & 408,64 \\
Saúde & 310,48 & 482,02 & 373,92 \\
Transporte & 315,54 & 261,99 & 45,92 \\
Poderes legislativo e judiciário & $\mathbf{4 4 2 , 3 9}$ & $\mathbf{2 9 3 , 6 6}$ & $\mathbf{2 9 7 , 5 6}$ \\
Total & $3.760,67$ & $4.379,09$ & $3.527,23$ \\
\hline
\end{tabular}


Ademais, como se nota nas figuras 14 e 15, em proporção do PIB, da renda domiciliar e da receita (pública) corrente líquida, a despesa com pessoal ativo do poder executivo fluminense é uma das menores (quando não a menor) em comparação com os demais estados. A ocupação de funções permanentes por cargos comissionados, prática excessiva de terceirizações, diversas áreas carentes de pessoal (em particular, prestadores de serviços essenciais) etc. denotam a falta de concurso, um problema estrutural que não só afeta a qualidade do serviço público como, inclusive, reduz a base de financiamento previdenciário. Ou seja, prejudica o ajuste em seu aspecto mais enfatizado na opinião pública.

Nesses termos, é importante também desmistificar a falsa impressão que o fundo previdenciário estadual tem um problema de trajetória, quando, na verdade, o que falta é a garantia de ativos suficientes desde sua origem. Nunca houve um plano de amortização para enfrentar isso e o governo fluminense ainda fez uma série de descapitalizações forçadas (R\$ 14,2 bilhões) para atender suas necessidades conjunturais de caixa em anos mais recentes, como aponta a tabela 7.

Figura 14. Despesa com pessoal ativo no poder executivo fluminense em \% do PIB e da Renda Domiciliar, 2015 Fonte: Afonso, 2016

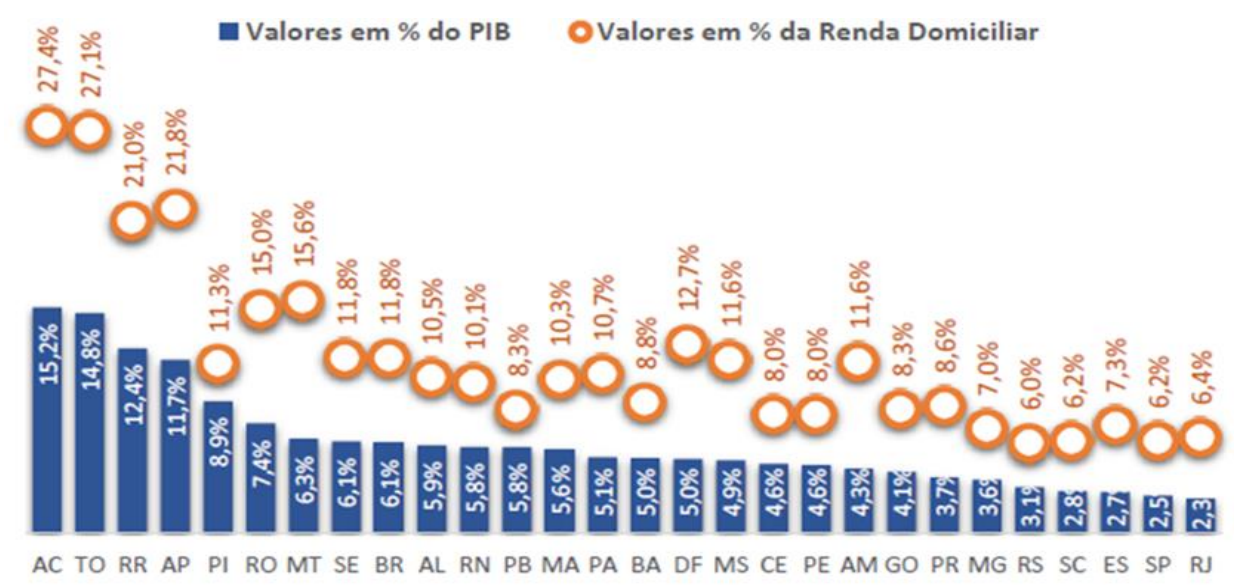

Figura 15. Despesa com pessoal ativo no poder executivo fluminense em \% da Receita Corrente Líquida, 2015 Fonte: Afonso, 2016

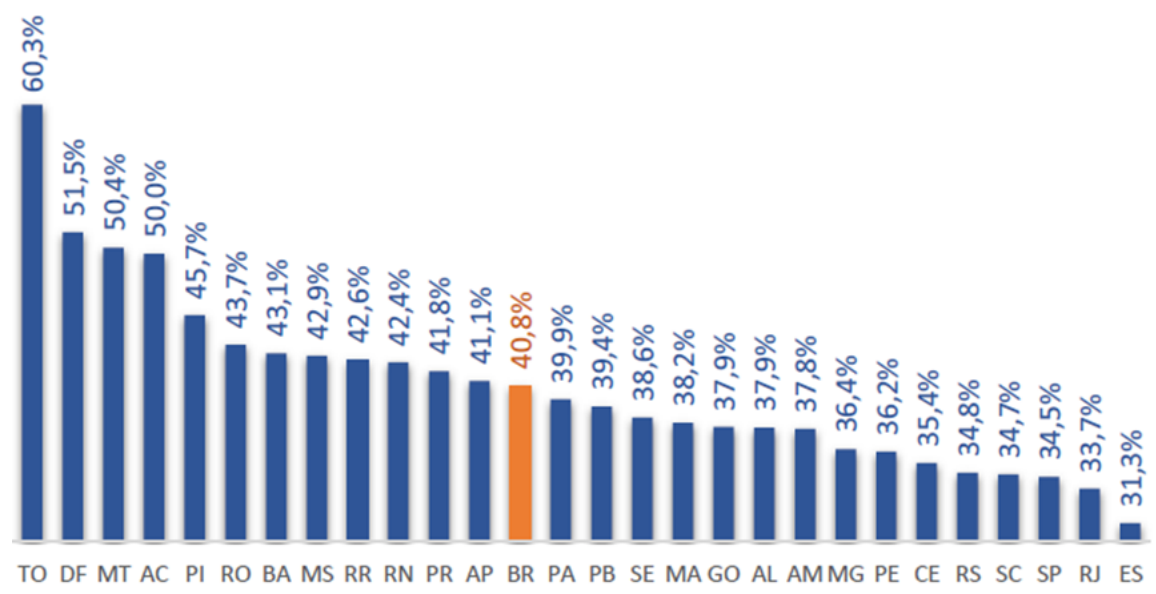


Tabela 7. Ações ou omissões do governo fluminense que levaram a descapitalização do Rioprevidência Fonte: TCE-RJ

\begin{tabular}{cc}
\hline Ações e Omissões & Valor (R\$ milhões) \\
\hline Não repasse da totalidade dos créditos de dívida ativa & 3.700 \\
Não recomposição do fluxo dos certificados Financeiros do Tesouro & 5.100 \\
Não repasse dos créditos tributários parcelados & 1.700 \\
Transferência de 13\% do ativo de royalties do petróleo para o Tesouro & 3.300 \\
Transferência de R\$ 450 milhões ao tesouro em troca de um terreno & 450 \\
Total & 14.250 \\
\hline
\end{tabular}

Do ponto de vista organizacional, estão em vigência dois modelos: um chamado "plano financeiro" (servidores civis ingressos antes de 09/2013 e militares) e outro chamado "plano previdenciário" (servidores civis ingressos depois de 09/2013). Segundo o mais recente cálculo atuarial apresentado nas figuras 16 e 17, não há déficit nesse último, só no primeiro que tende a encolher quase totalmente no tempo (pois só entra nele novos militares).

O discurso oficial oculta que o cerne da questão não é mais estrutural, dado que já está encaminhado, e sim dos efeitos de curto e médio prazos que se revertem em um custo de transição. Por lei estadual (6.338/2012), são duas gestões distintas e as insuficiências já uma questão específica, a previdência estadual não é a razão da crise muito menos a via de sua solução esperadas do "plano financeiro" devem ser aportadas pelo ente governamental ${ }^{3}$.

Portanto, o que está totalmente desajustado nas contas públicas fluminense são decisivamente as receitas. Isso se deve por questões tributárias e federativas não enfatizadas em uma proposta focada no retorno rápido e melhor para o governo federal como credora, enquanto esboça tolerância com a dívida ativa de empresas com o próprio governo (segundo Ministério Público, o índice de recuperação foi de só 1\% em 2015).

\footnotetext{
3 É um equívoco discutir a previdência sem separar os dois planos, pois segundo o artigo 11 da referida lei estadual: "a segregação dos Planos Financeiro e Previdenciário deverá ser acompanhada pela separação orçamentária, financeira, contábil e dos investimentos dos recursos e obrigações correspondentes". E as insuficiências já esperadas do Plano Financeiro devem ser aportadas pelo governo estadual, conforme texto do artigo 2, capítulo XXI: "Plano Financeiro: sistema estruturado somente no caso de segregação da massa, no qual as contribuições a serem pagas pelo ente federativo, pelos servidores ativos e inativos e pelos pensionistas vinculados são fixadas sem objetivo de acumulação de recursos, sendo as insuficiências aportadas pelo ente federativo, admitida a constituição de fundo financeiro".
} 
Figura 16. Evolução do cálculo atuarial do Plano Financeiro do Rioprevidência, 2016/2095 Fonte: Rioprevidência

\section{Plano Financeiro}

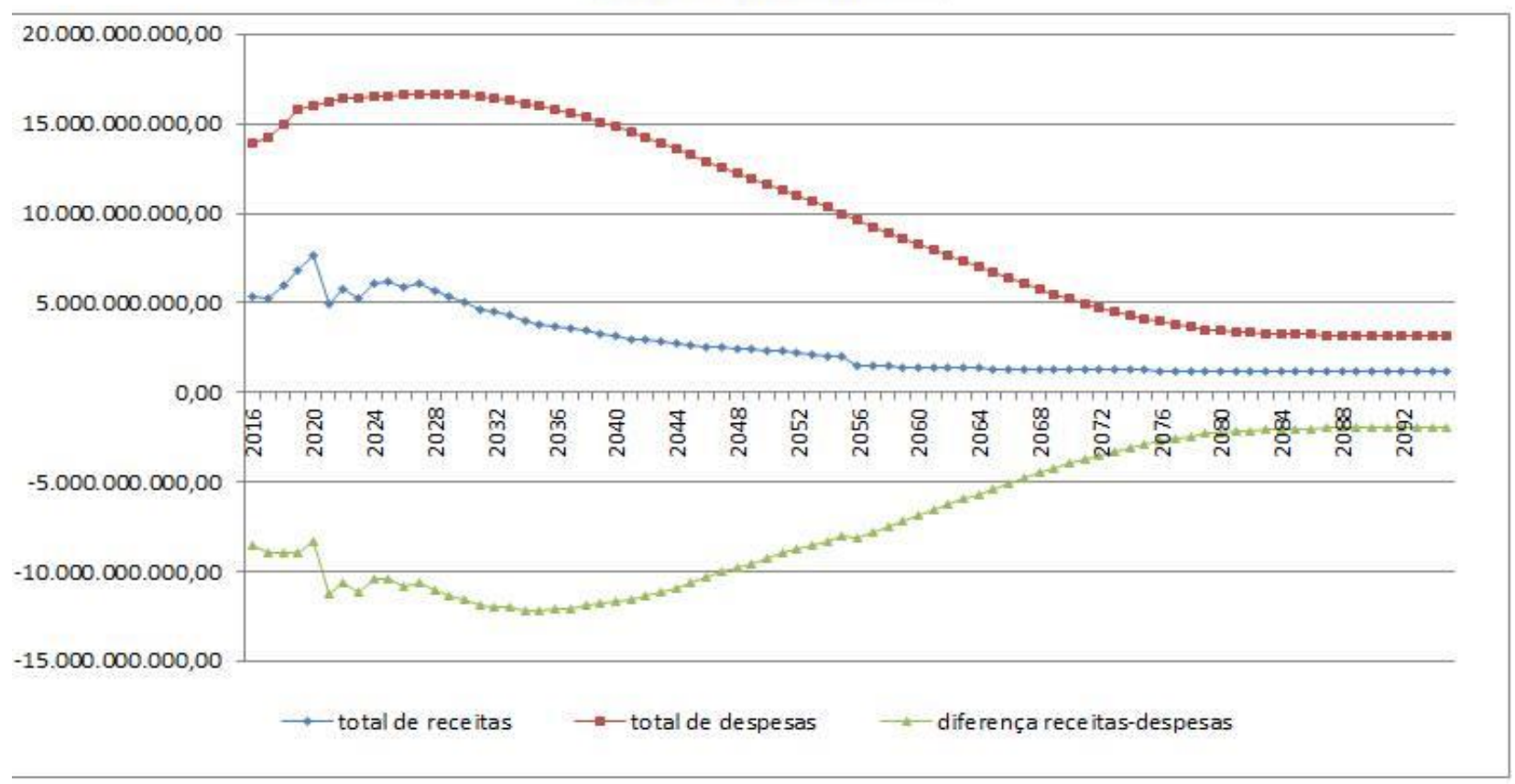

Figura 17. Evolução do cálculo atuarial do Plano Previdênciário do Rioprevidência, 2016/2095 Fonte: Rioprevidência

\section{Plano Previdenciário}

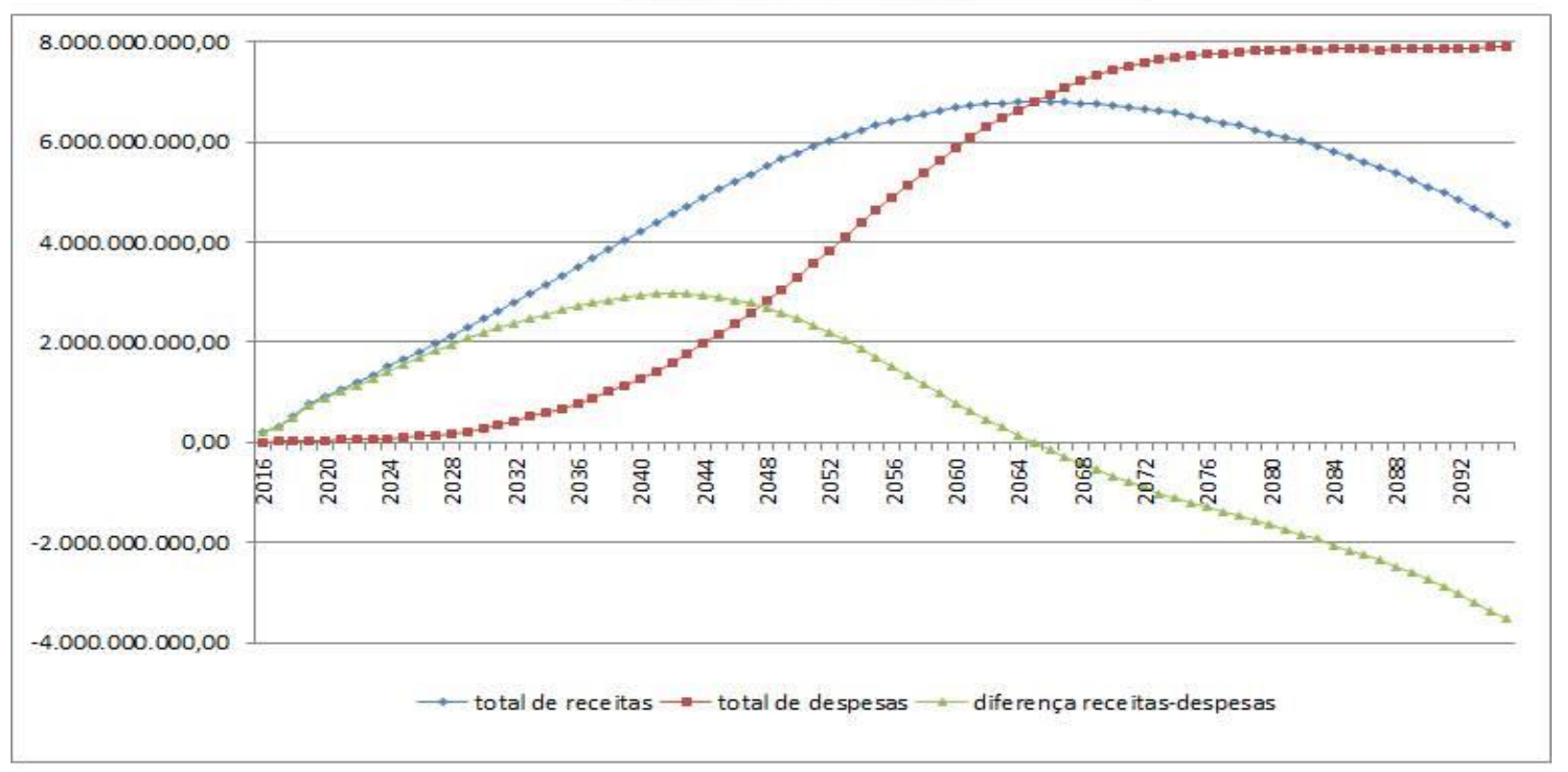

Atualmente, a dívida estadual é de cerca de $\mathrm{R} \$ 107$ bilhões, sendo que $\mathrm{R} \$ 73,6$ bilhões diretamente com a União. Segundo tabela 8, os principais itens são associados aos acordos de renegociação da dívida do final da década de 1990, repara-se que até hoje não foram quitados embora o saldo atual (o que falta pagar e não 
tudo que já foi pago) signifique mais que o triplo do valor contratado. Em valores de janeiro de 2017, isso garante a União um fluxo de desembolso mensal de 127,7 milhões. Causa espécie a gestão federal não aceitar discutir o perdão de parte do montante (em 2016, a dívida chegou a $\mathrm{R} \$ \mathbf{7 3 , 6}$ bilhões) e cobrar de forma implacável um valor próximo do endividamento das empresas com o governo estadual (R\$ 69 bilhões). Destaca-se que, segundo dados do ministério público, mais de 6 bilhões da dívida ativa se refere a Petrobrás e aos Correios, duas empresas estatais federais.

Tabela 8. Montante da dívida do governo fluminense por credor do Estado do Rio de Janeiro Fonte: Tesouro Nacional e SEFAZ-RJ

\begin{tabular}{|c|c|c|c|c|}
\hline \multirow{2}{*}{ Dívida } & \multicolumn{2}{|c|}{ Valor contratado (R\$ bi) } & \multicolumn{2}{|c|}{ Saldo 12/2016 (R\$ bi) } \\
\hline & nominal & Part. & nominal & Part. \\
\hline TOTAL - DÍVIDA FINANCEIRA & 54,7 & $100,0 \%$ & 107,0 & $100,0 \%$ \\
\hline ADM DIRETA - DÍVIDA FUNDADA & 54,6 & $99,7 \%$ & 106,9 & $99,9 \%$ \\
\hline Interna & 45,0 & $82,2 \%$ & 95,3 & $89,1 \%$ \\
\hline UNIÃO & 23,0 & $42,1 \%$ & 73,6 & $68,8 \%$ \\
\hline BACEN - Assunção Div. BERJ & 3,9 & $7,1 \%$ & 14,7 & $13,7 \%$ \\
\hline BONUS/DMLP & 0,0 & $0,0 \%$ & 0,1 & $0,1 \%$ \\
\hline Refin. Lei Federal no 8.727/93 - ESTADO & 0,1 & $0,2 \%$ & 0,0 & $0,0 \%$ \\
\hline Refin. Lei Federal $n \circ$ 8.727/93 - CEHAB & 0,5 & $0,9 \%$ & 0,0 & $0,0 \%$ \\
\hline Refin. Lei Federal no 8.727/93 - BANERJ & 0,0 & $0,0 \%$ & 0,0 & $0,0 \%$ \\
\hline Refin. Lei Federal no 9.496/97 & 18,5 & $33,9 \%$ & 58,8 & $55,0 \%$ \\
\hline CAIXA ECONÔMICA & 3,1 & $5,6 \%$ & 2,0 & $1,9 \%$ \\
\hline SECRETARIA DA RECEITA FEDERAL & 1,3 & $2,3 \%$ & 0,8 & $0,8 \%$ \\
\hline BANCO DO BRASIL & 7,9 & $14,4 \%$ & 10,0 & $9,4 \%$ \\
\hline BNDES & 8,7 & $15,9 \%$ & 7,7 & $7,2 \%$ \\
\hline CREDIT SUISSE & 1,1 & $1,9 \%$ & 1,2 & $1,1 \%$ \\
\hline Externa & 9,6 & $17,6 \%$ & 11,6 & $10,8 \%$ \\
\hline BID & 1,6 & $2,9 \%$ & 0,9 & $0,8 \%$ \\
\hline Japan Bank for International Cooperation & 0,1 & $0,2 \%$ & 0,1 & $0,1 \%$ \\
\hline BIRD & 5,6 & $10,2 \%$ & 7,5 & $7,0 \%$ \\
\hline Agência Francesa de Desenvolvimento & 0,8 & $1,5 \%$ & 1,2 & $1,2 \%$ \\
\hline Corporação Andina de Fomento & 1,5 & $2,8 \%$ & 1,8 & $1,7 \%$ \\
\hline Títulos & 0,0 & $0,0 \%$ & 0,0 & $0,0 \%$ \\
\hline ADM INDIRETA - CUSTEADA (F.TESOURO) & 0,1 & $0,3 \%$ & 0,1 & $0,1 \%$ \\
\hline
\end{tabular}

Configura-se um processo de "solidarização de perdas" em favor de poucos. Enquanto a dívida entre entes governamentais não é contestada, muitos políticos se apressam em tomar como impagável boa parte da dívida privada. Soma-se a letargia na aprovação de autorização legal para sua securitização, o que permitiria uma receita extraordinária importante (ganho previsto de R\$ 3 bilhões).

Desconsidera-se ainda uma revisão do Fundo de Participação Estadual e uma série de ressarcimentos que, anualmente, poderia gerar um fluxo em torno de $\mathrm{R} \$ 15,5$ bilhões a mais. Por exemplo, a Fundação Amazônia de Amparo a Estudos e Pesquisas (FAPESPA) fez o ranking das perdas tributárias com a Lei Kandir. Como aponta a tabela 9, depois de Minas Gerais, o Rio de Janeiro é o estado mais prejudicado (R\$ 49,2 bilhões 
acumulados), sendo que, em 2015, já seriam $\mathrm{R} \$ 4,5$ bilhões de perdas ao ano. Soma-se o atraso da ANP em atualizar cálculos de royalties e participações especiais por pressão das petroleiras, levando a cerca de R\$ 1 bilhão de perdas (além de valores retroativos) ${ }^{4}$. Por fim, o ICMS para extração e refino do petróleo ser ainda cobrado no destino provoca uma perda anual em torno de R\$ 10 bilhões (segundo estimativa da SEDEIS-RJ).

Tabela 9. Ranqueamento por estados selecionados e grandes regiões das perdas de arrecadação com lei Kandir, 1997/2015 Fonte: FAPESPA Nota: valores corrigidos pelo IPCA, dez. 2015

\begin{tabular}{lcccccc}
\hline & 1997 & Rank 1997 & 2015 & Rank 2015 & $1997-2015$ & Rank97-15 \\
\hline Minas Gerais & 1.738 & 1 & 7.239 & 1 & 92.181 & 1 \\
Rio de Janeiro & $\mathbf{1 . 6 2 5}$ & $\mathbf{2 7}$ & $\mathbf{4 . 4 7 2}$ & $\mathbf{5}$ & $\mathbf{4 9 . 2 1 9}$ & $\mathbf{2}$ \\
Pará & 556 & 6 & 3.527 & 7 & 44.168 & 3 \\
Rio Grande do Sul & 1.148 & 2 & 4.505 & 4 & 41.776 & 4 \\
Mato-Grosso & 87 & 12 & 5.406 & 2 & 41.753 & 5 \\
Sudeste & 1.711 & - & 19.587 & - & 215.122 & - \\
Sul & 2.037 & - & 9.940 & - & 96.126 & - \\
Centro-Oeste & 203 & & 9.820 & - & 73.477 & - \\
Norte & 602 & - & 4.390 & - & 47.900 & - \\
Nordeste & 438 & & 3.592 & - & 34.265 & - \\
Brasil & 4.991 & - & 47.329 & - & 466.890 & - \\
\hline
\end{tabular}

\section{CONCLUSÃO}

É preciso nacionalizar a crise no Rio a fim de não confiar cegamente em uma proposta que a trata como crise do Rio. É preciso explicitar a tensão federativa ocultada por uma moral de tesouraria que não consegue ir além da aparência do problema refletida em uma soma dos desequilíbrios. Cabe se indagar por que uns mantém suas estruturas de gasto e outros se veem impedidos, bem como por que uns controlam os mecanismos de poder de compra e outros estão vulneráveis e desfinanciados.

Por exemplo, evitar que a gravidade do quadro de violência fluminense se explicite é uma preocupação que deveria ser considerada de interesse nacional pela sua dimensão e pelos efeitos sobre o resto do país. Segundo LOA 2017, 15,6\% do orçamento estadual é dispêndio em segurança, o que significa mais de R\$ 12 bilhões anuais. É preciso ter clareza que a escala crescente de custos da área no Estado do Rio de Janeiro transcendem a um quadro normal no nível estadual e de sua capacidade financeira, em especial, tendo se realizado diversos concursos para novos soldados e realizado a experiência de Unidades de Política Pacificadora - UPPs.

O que se evidencia é o peso da lógica assimétrica de tomada de decisão entre os entes da federação. Uma alternativa mais razoável exige questionar três aspectos centrais:

\footnotetext{
${ }^{4}$ Além disso, o repasse de royalties e participações especiais leva, em média, 60 dias de atraso após o recolhimento feito ao Tesouro Nacional e sem correção monetária. Segundo Procuradoria Geral do Estado do Rio (PGE-RJ), isso significa perda de receita de R\$ 522 milhões entre 2012 a 2016.
} 
1) Atribuiu-se a crise como um problema exclusivo estadual quando a escala do problema é nacional.

2) O governo federal assumiu o papel simplesmente de credor sem a redistribuição de competências e recursos no âmbito do pacto federativo (incluindo recompartilhamento de custos como segurança).

3) Não articulação do problema das finanças públicas aos efeitos imprevisíveis de uma grave crise econômica.

Por essa razão, em caráter emergencial, caberiam não novos empréstimos e sim o governo federal fazer transferências voluntárias assumindo suas responsabilidades. No aspecto estrutural, precisa-se ir além de um debate contábil focado em gestão e orçamento, e enxergar o sentido mais amplo e profundo de um processo no qual o Estado e o planejamento público no Rio de Janeiro precisam ser resgatados em seu papel mais estratégico para lidar com sua debilidade produtiva.

Do ponto de vista do diagnóstico, a folha com pessoal estar pesando na receita corrente pode ser entendido também pelo fato dessa receita ter tido uma queda fortíssima recentemente e ter uma trajetória de longo prazo comparativamente pior que de outros estados. Ou seja, se tivesse uma recuperação de receitas e uma economia capaz de sustentar uma massa de arrecadação compatível ao porte da economia fluminense esse dito peso da folha seria menor. O peso do custo com inativos ser não desprezível pode ser entendido pelo fato de a máquina pública ser modesta. Ou seja, comparativamente com outros estados o gasto com pessoal ativo do executivo no Estado do Rio de Janeiro é pequeno. Se tivéssemos reestruturado a máquina pública, esse peso dos inativos seria reduzido e mais, teríamos inclusive mais ativos para contribuir com a previdência.

Portanto, a manifestação da crise no Rio não é por excesso de despesa com pessoal e sim por falta de receita estruturalmente e algo agravado conjuntamente (junto ainda a uma perigosa trajetória de endividamento). E mais, o problema não é ter muito inativo e sim ter um Estado desorganizado em suas funções estratégicas e uma estrutura produtiva débil para garantir uma arrecadação compatível ao porte da economia fluminense. Diante disso, o servidor não é o problema, e sim a solução se for entendido o desafio de fortalecer a máquina pública e os impactos positivos que isso pode ter para uma recuperação e desenvolvimento produtivo ao se reestruturar a capacidade de planejamento público e políticas estruturantes (vide ciência e tecnologia). Infelizmente, as perspectivas com a gestão estadual atual alinhada ao governo 
federal são no sentido inverso: desvalorizando o serviço público, atrofiando as políticas estratégicas e desatento a debilidade da estrutura econômica.

\section{REFERÊNCIAS}

AFONSO, J.R.; PINTO, V. "Despesa pessoal com pessoal ativo e do executivo: uma comparação entre unidades federativas". Caderno virtual do IDP, v.2, n.35, 2016.

DWECK, E (2017). "A crise do Estado do Rio de Janeiro e o impacto nos programas de pós-graduação e na pesquisa". Apresentação no Programa de Pós-Graduação em Saúde Coletiva IMS/UERJ, 10 de março de 2017.

OSORIO, M. Território Fluminense (coluna), Jornal Extra, 10 de novembro de 2016, p.4.

OSORIO, M. Rio nacional/ Rio local. Rio de Janeiro: SENAC Rio, 2005

SOBRAL, B. "A evidência da estrutura produtiva oca: o Estado do Rio de Janeiro como um dos epicentros da desindustrialização nacional". In: MONTEIRO NETO et al. Desenvolvimento Regional no Brasil: Políticas, estratégias e perspectivas. Brasília: IPEA, 2017, pp. 398-426.

SOBRAL, B. Metrópole do Rio e Projeto Nacional. Rio de Janeiro: Garamond, 2013. 